\title{
Hydroponic cultivation of Oncidium baueri
}

\section{Cultivo hidropônico de Oncidium baueri}

\author{
Daniele Brandstetter Rodrigues ${ }^{1 *}$; Adriane Marinho de Assis ${ }^{2}$; Ricardo Tadeu \\ Faria $^{3}$; Marcia Wulff Schuch²; Roberta Marins Nogueira Peil ${ }^{2}$
}

\begin{abstract}
In Brazil, orchid cultivation has been increasing steadily over the last few years and contributing significantly to the economy. It has been reported that several vegetable crops and ornamentals have been successfully grown by soilless cultivation. The orchid Oncidium baueri Lindl. is grown on pot substrates. Nevertheless, hydroponics is an excellent alternative, especially for the production of cut flowers and bare root plants. The objective of this study was to evaluate the development of Oncidium baueri on two soilless systems: (a) pots containing Amafibra ${ }^{\circledR}$ coconut fiber, carbonized rice husk, and pine bark (1:1:1) irrigated with nutrient solution every $15 \mathrm{~d}$; and (b) a nutrient film technique (NFT) hydroponic system irrigated with nutrient solution daily. Shoot height, pseudobulb diameter, and number of sprouts were evaluated monthly. The number of flowering plants, number of flowers, dry mass of shoots, and dry mass of roots were evaluated 11 months after onset of experiment. The pot cultivation system yielded more flowers and higher values for all vegetative parameters than the NFT hydroponic system.
\end{abstract}

Key words: NFT. Orchid. Nutrient solution. Substrate.

\section{Resumo}

No Brasil, o cultivo de orquídeas vem crescendo continuamente ao longo dos últimos anos, contribuindo de forma significativa na economia do país. O cultivo sem solo tem sido relatado com sucesso para diversas espécies hortícolas. Para a orquídea Oncidium baueri Lindl., além do uso de substratos em vaso, a hidroponia pode representar uma alternativa interessante. Assim, o objetivo deste trabalho foi avaliar o desenvolvimento de Oncidium baueri em dois sistemas de cultivo sem solo: em vasos contendo fibra de coco Amafibra ${ }^{\circledR}$-casca de arroz carbonizada+casca de pinus (1:1:1) e irrigadas com solução nutritiva a cada quinze dias e irrigadas diariamente com solução nutritiva em sistema hidropônico do tipo NFT. $\mathrm{O}$ delineamento experimental foi em blocos completos casualizados, com seis repetições, sendo cada parcela composta por seis plantas. Foram avaliados mensalmente a altura de parte aérea, o diâmetro do pseudobulbo, o número de brotações e, após 11 meses, o número de plantas florescidas e de flores emitidas por planta, a massa seca da parte aérea e das raízes. O sistema de cultivo em vaso contendo substrato propiciou o florescimento das plantas ao final do experimento e os melhores resultados para todas as variáveis vegetativas avaliadas, propiciando maior crescimento e desenvolvimento de Oncidium baueri do que o cultivo hidropônico do tipo NFT.

Palavras-chave: NFT. Orquídea. Solução nutritive. Substrato.

1 Discente, Curso de Doutorado, Programa de Pós-Graduação em Ciência e Tecnologia de Sementes, Universidade Federal de Pelotas, UFPel, Pelotas, RS, Brasil. E-mail: ufpelbrandstetter@hotmail.com

2 Profs., Departamento de Fitotecnia, UFPel, Pelotas, RS, Brasil. E-mail: agroadri17@gmail.com; marciaws@ufpel.edu.br; rmnpeil@gmail.com

3 Prof. Dr., Departamento de Agronomia, Universidade Estadual de Londrina, UEL, Londrina, PR, Brasil. E-mail: faria@uel.br

* Author for correspondence

Received: Aug. 11, 2016 Approved: Jan. 20, 2017 
Orchids belonging to the genus Oncidium, are epiphytes that grow sympodially, produce flat and striated pseudobulbs. Oncidium baueri, known as "golden shower", is highly valued for the numerous yellow blossoms distributed along its stem. It is commercialized as a cut flower, a potted plant, or a plant for landscape projects (FARIA et al., 2006; LORENZI; SOUZA, 2001). In Brazil, orchid cultivation has been increasing steadily in recent years and has contributed significantly to the nation's economy. Therefore, many growers have been producing them in protected environments using pots containing various substrates (COLOMBO et al., 2005; YAMAKAMI et al., 2006; ZANDONÁ et al., 2014). Nevertheless, there is little information about the best substrates for pot cultivation of Oncidium baueri in the south region of Rio Grande do Sul.

A promising alternative in soilless orchid cultivation for the cut flower and bare-root seedling markets is nutrient film technique (NFT) hydroponics (nutrient laminar flow). One advantage of this system is that it supplies mineral nutrients, water, and oxygen to the plant very efficiently. The absence of substrates eliminates the need for disinfecting materials and supports a high plant density (CARRASCO; IZQUIERDO, 1996). With the NFT, cultivation occurs in a protected environment, physical space is utilized more efficiently, pest and disease incidences are reduced, fewer pesticide treatments are required, nutrient medium distribution is better regulated for plant growth, and less contamination of groundwater by nitric nitrogen and other chemical elements (NEVES et al., 2005).

The efficiency of the NFT system has been demonstrated in the cultivation of leafy vegetables (FAQUIM; FURLANI, 1999) and fruits (ALBUQUERQUE NETO; PEIL, 2012; MARQUES et al., 2014; STRASSBURGER et al., 2011). Nevertheless, there is no data on the adaptation of Oncidium baueri to this production method. Thus, the aim of this study was to assess the development of Oncidium baueri in two soilless cultivation systems (pots containing substrate, and a NFT hydroponic system).

Oncidium baueri seedlings were obtained from the State University of Londrina (UEL)-PR. Their mean shoot height was $33 \pm 6.92 \mathrm{~cm}$. Three pseudobulbs were retained on each seedling, and the roots were completely pruned. The plants were maintained in a greenhouse covered with a transparent low-density polyethylene (LDPE) film $150 \mu \mathrm{m}$ in thickness. Between December 2013 and March 2014, the film was covered with a 50\% aluminized thermal-reflective screen positioned at a height of $1.10 \mathrm{~m}$ above the plants. The soil was covered with $150-\mu \mathrm{m}$ thick double-sided black/ white polyethylene film with the white side facing up. The greenhouse vents were opened or closed according to daily weather conditions.

Each NFT hydroponic apparatus consisted of two paired cultivation channels (100-mm PVC pipes) 2 $\mathrm{m}$ in length and placed on wooden stands $0.85 \mathrm{~m}$ above the soil surface. A $2 \%$ slope was maintained to drain the nutrient solution toward a drainpipe (50$\mathrm{mm}$ PVC tube) bringing the solution to a reservoir $(100 \mathrm{~L})$. Each cultivation channel contained six plants spaced at $0.50 \mathrm{~m}$ intervals. The roots were inserted in phenolic foam blocks $(5 \times 5 \times 9 \mathrm{~cm})$ to keep the plants upright. The nutrient solution was supplied via a low-power $(1 / 2 \mathrm{cv})$ electropump and a programmed timer.

In the substrate-based cultivation system, the seedlings were individually transplanted to polyethylene pots $10 \mathrm{~cm}$ high and $12 \mathrm{~cm}$ wide. Their capacity was $1 \mathrm{~L}$ and they had five drainage holes in the inner surface. One layer of expanded clay was packed on the bottom to provide drainage and root aeration. A mixture of coconut fiber (Standard 70 Amafibra $^{\circledR}$ ), carbonized rice husk, and pine bark $(1: 1: 1)$ was used as a substrate (SORACE et al., 2008). The pots were placed at $0.50 \mathrm{~m}$ intervals on benches $0.85 \mathrm{~m}$ above the ground.

The nutrient solution was formulated based on the mineral content in the tissues of Cattleya spp. 
orchids (CORTÉS et al., 1999). Macronutrient concentrations were as follows: $7.1 \mathrm{mmol}^{-\mathrm{L}^{-1}}$ $\mathrm{NO}_{3}^{-} ; 1.0$ mmol-L ${ }^{-1} \mathrm{H}_{2} \mathrm{PO}_{4}^{-} ; 0.7 \mathrm{mmol}-\mathrm{L}^{-1} \mathrm{SO}_{4}{ }^{2-}$;

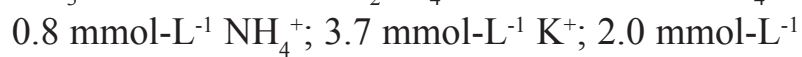
$\mathrm{Ca}^{2+}$; and 0.5 mmol- $\mathrm{L}^{-1} \mathrm{Mg}^{2+}$. Micronutrient concentrations were as follows: $0.5 \mathrm{mg}-\mathrm{L}^{-1} \mathrm{Mn}$; $0.05 \mathrm{mg}-\mathrm{L}^{-1} \mathrm{Cu} ; 0.3 \mathrm{mg}-\mathrm{L}^{-1} \mathrm{~B}$; $0.5 \mathrm{mg}-\mathrm{L}^{-1} \mathrm{Zn} ; 3$ Fe; and $0.07 \mathrm{mg}^{-\mathrm{L}^{-1}} \mathrm{Mo}$. In the NFT system, plants were irrigated between four and ten times per day depending on the season and the availability of atmospheric moisture.

Potted plants were irrigated manually by adding $200 \mathrm{~mL}$ water from a beaker to each pot. Irrigation frequency varied according to weather conditions. Fertigation with a nutrient solution
$(250 \mathrm{~mL} /$ pot) was performed once every $15 \mathrm{~d}$. The electrical conductivities $\left(\mathrm{dS} \mathrm{m} \mathrm{m}^{-1}\right)$ and $\mathrm{pH}$ of the nutrient solutions in the tanks were monitored daily using manual digital conductivity and $\mathrm{pH}$ meters, respectively. The $\mathrm{pH}$ was maintained between $4.5-$ 5.5 either by adding $1 \mathrm{~N} \mathrm{KOH}$ to raise it or $\mathrm{H}_{2} \mathrm{SO}_{4}$ to lower it. The electrical conductivity was maintained between $0.8-1.5 \mathrm{dS} \mathrm{m}^{-1}$.

The global solar radiation incident on the outside of the greenhouse (Figure 1) was obtained from data collected at the Agroclimatological Station of Pelotas $\sim 450 \mathrm{~m}$ from the experimental site. Maximum and minimum temperatures $\left({ }^{\circ} \mathrm{C}\right)$ inside the greenhouse (Figure 2) were recorded daily using a thermohygrometer in a shelter.

Figure 1. Monthly mean values of daily external global solar radiation $\left(\mathrm{cal} \mathrm{cm}^{-2} \cdot \mathrm{day}^{-1}\right)$ during the experiment. Pelotas, UFPel, 2013/14.

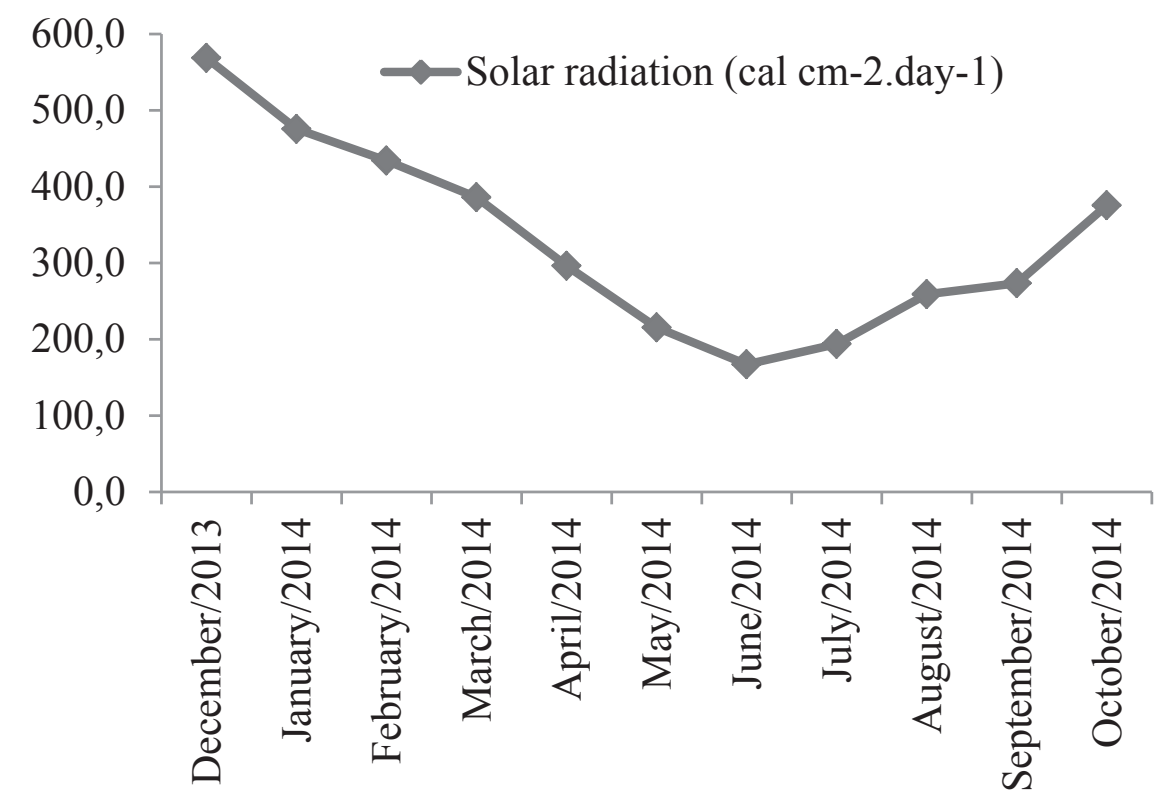

Measurements of the shoot height (cm), pseudobulb diameter $(\mathrm{cm})$, and number of sprouts were taken monthly. A measuring tape was used to measure the shoot and pseudobulb diameter (medial portion). Eleven months after the start of the experiment, the number of flowering plants, the number of flowers per plant, and the dry mass of the shoots and roots were evaluated. The material was maintained in a drying oven with air renewal/ circulation at $65^{\circ} \mathrm{C}$ until a constant weight was reached. Weights were determined using precision balances. 
The experiment was designed as two-factorial for the non-destructive variables. The first factor was the cultivation system (substrate-based or hydroponics) and the second factor was the month of assessment (11 levels). The experiment was designed as unifactorial (cultivation system) for the dry mass of the shoots and roots. The experimental design consisted of completely randomized blocks with six replicates. Each plot consisted of six plants.

In the NFT system, each experimental plot consisted of cultivation channels ( $2 \mathrm{~m}$ long). In the substrate-based cultivation system, each plot consisted of six pots arranged in a line on the bench. The data were subjected to ANOVA and the means were compared using Tukey's test at a 5\% significance level.
ANOVA indicated that there was a significant interaction between the cultivation system and the month of assessment for shoot height and pseudobulb diameter. Nevertheless, the interaction between the two factors was not significant for the number of sprouts.

A similar pattern was obtained for shoot height and pseudobulb diameter (Table 1). The pot substrate cultivation system was more efficient than the hydroponic system between 90 $\mathrm{d}$ after transplantation (February) until the end of the experimental period except for the March assessment when no significant differences were found between the systems in terms of shoot height and pseudobulb diameter.

Table 1. Plant height, pseudobulb diameter, and number of sprouts during the 11 months of Oncidium baueri cultivation in pots with substrates and in a hydroponic system. Pelotas, UFPel, 2013/14.

\begin{tabular}{lcccccc}
\hline & \multicolumn{2}{c}{ Plant height $(\mathrm{cm})$} & \multicolumn{2}{c}{ Pseudobulb diameter $(\mathrm{cm})$} & \multicolumn{2}{c}{ Number of Sprouts* } \\
\hline Month & Substrate & Hydroponics & Substrate & Hydroponics & Substrate & Hydroponics \\
\hline December/13 & $30.89 \mathrm{bA} * *$ & $31.30 \mathrm{abcA}$ & $7.23 \mathrm{bA}$ & $6.77 \mathrm{aA}$ & $0 \mathrm{c}$ & $0 \mathrm{c}$ \\
January/14 & $33.88 \mathrm{abA}$ & $30.44 \mathrm{abcA}$ & $7.20 \mathrm{bA}$ & $6.60 \mathrm{aA}$ & $0 \mathrm{c}$ & $0 \mathrm{c}$ \\
February/14 & $35.67 \mathrm{abA}$ & $30.66 \mathrm{abcB}$ & $7.42 \mathrm{bA}$ & $6.50 \mathrm{aB}$ & $0 \mathrm{c}$ & $0 \mathrm{c}$ \\
March/14 & $36.19 \mathrm{abA}$ & $32.06 \mathrm{abA}$ & $7.40 \mathrm{bA}$ & $7.07 \mathrm{aA}$ & $0 \mathrm{c}$ & $0 \mathrm{c}$ \\
April/14 & $39.41 \mathrm{aA}$ & $34.36 \mathrm{aB}$ & $8.25 \mathrm{abA}$ & $6.66 \mathrm{aB}$ & $0 \mathrm{c}$ & $0 \mathrm{c}$ \\
May/14 & $39.36 \mathrm{aA}$ & $33.94 \mathrm{aB}$ & $9.19 \mathrm{aA}$ & $6.90 \mathrm{aB}$ & $0 \mathrm{c}$ & $0 \mathrm{c}$ \\
June/14 & $39.89 \mathrm{aA}$ & $33.64 \mathrm{aB}$ & $7.83 \mathrm{bA}$ & $6.74 \mathrm{aB}$ & $0 \mathrm{c}$ & $0 \mathrm{c}$ \\
July/14 & $38.64 \mathrm{aA}$ & $30.63 \mathrm{abcB}$ & $7.79 \mathrm{bA}$ & $6.91 \mathrm{aB}$ & $0.67 \mathrm{c}$ & $0.33 \mathrm{c}$ \\
August/14 & $37.69 \mathrm{abA}$ & $30.50 \mathrm{abcB}$ & $8.14 \mathrm{abA}$ & $6.91 \mathrm{aB}$ & $1.51 \mathrm{~b}$ & $0.98 \mathrm{~b}$ \\
September/14 & $37.05 \mathrm{abA}$ & $25.03 \mathrm{bcB}$ & $7.76 \mathrm{bA}$ & $6.64 \mathrm{aB}$ & $1.94 \mathrm{ab}$ & $1.66 \mathrm{ab}$ \\
October/14 & $41.25 \mathrm{aA}$ & $23.97 \mathrm{cB}$ & $8.29 \mathrm{abA}$ & $6.54 \mathrm{aB}$ & $2.58 \mathrm{a}$ & $1.91 \mathrm{a}$ \\
\hline Means & $37.26 \mathrm{~A}$ & $30.59 \mathrm{~B}$ & $7.87 \mathrm{~A}$ & $6.75 \mathrm{~B}$ & $0.61 \mathrm{~A}$ & $0.44 \mathrm{~B}$ \\
\hline CV $(\%)$ & 7.96 & & 6.41 & & 57.19 \\
\hline
\end{tabular}

*No significant interaction between factors. **Means followed by same letter (upper case in row comparing cultivation systems; lower case in column comparing assessment months) for each variable did not significantly differ according to Tukey's test at a $5 \%$ significance level.

The highest means for plant height were recorded between April and June in both systems. Thereafter, plant heights decreased between July and September in the substrate-based system, and between July and the end of the assessment period in the hydroponic system. In October, plant heights increased in the pot substrate system and significantly decreased in the plants raised in the hydroponic system (Table 1). 
The pseudobulb diameters of the substrate-based plants varied throughout the assessment period. The values were highest in April, May, August, and October (final assessment). The pseudobulb diameters of the plants grown in the hydroponic system, however, did not vary throughout the assessment period (Table 1). Therefore, hydroponic cultivation did not significantly promote pseudobulb growth in Oncidium baueri plants. Pseudobulb size is essential in orchid growth and development because it stores water and carbohydrates, and is significantly involved in metabolic energy supply (ASSIS et al., 2003).

After the first months of adaptation to the new cultivation conditions, the plants began to exhibit shoot growth and height increases (Table 1). This change was observed in early January for the substrate-based plants, and in March, for the NFT plants.

The greatest mean heights in both systems were observed from April to June, and the largest mean pseudobulb diameters were first observed in April and May only in the substrate-based plants. In this period, solar radiation (Figure 1) and temperature (Figure 2) were at intermediate levels typical of autumn in the southern region of Brazil. These conditions favor plant growth. In June, the mean temperature decreased to $17^{\circ} \mathrm{C}$ from the $23^{\circ} \mathrm{C}$ recorded in April.

Figure 2. Monthly minimum, maximum, and mean air temperatures $\left({ }^{\circ} \mathrm{C}\right)$ inside the greenhouse throughout the Oncidium baueri cultivation period. Pelotas, UFPel, 2013/14.

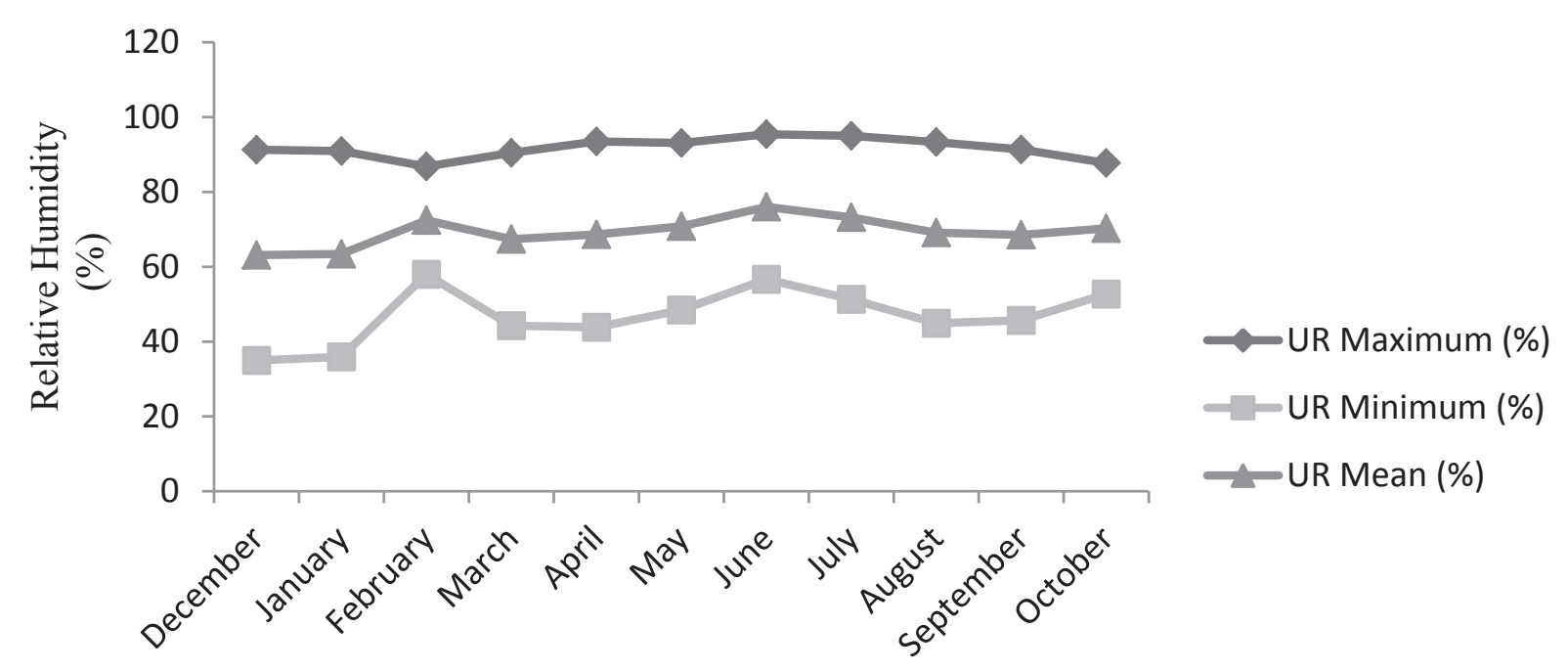

Months of the year

(december/13 - october/14)

In the substrate-based cultivation system, pseudobulb diameters decreased in June and July, and plant height decreased between July and September. In the plants cultivated in the hydroponic system, height decreased between July and the end of the assessment period. The decrease in plant height may have been correlated with reduced solar radiation (Figure 1) and with low winter temperatures $\left(<10^{\circ} \mathrm{C}\right.$ minimum between June and August) (Figure 2). These led to decreases in plant metabolism and growth. Evaporative water demand was very low during this period, which hindered water flow to the plants, caused a loss of turgor, and reduced pseudobulb diameter 
and height. The decreases in solar radiation and temperature may have also induced leaf abscission in the hydroponically cultivated plants.

As solar radiation and temperature increased at the end of winter and the beginning of spring, the plants raised on substrate resumed growth. Pseudobulb diameter increased in August and October, and height significantly increased in October. This recovery, however, was not observed in the plants cultivated hydroponically.

The number of sprouts was higher in the plants cultivated on substrates than grown hydroponically in all assessments from July onwards. At the end of the experimental period, the substrate-based plants had a mean of 0.61 sprouts whereas those in the hydroponic system had an average of 0.44 sprouts (Table 1). Sprouts began to appear only in July, which indicated that, for the first seven- to eight months of the trial, the plants were adapting to their new cultivation environments.

The lower values of the non-destructive variables obtained for the hydroponic plants (Table 1) indicated that there were significant decreases in shoot and root dry matter production (Table 2). The shoot and root dry masses of the substratebased plants were approximately three- and twofold greater than those of the hydroponically grown plants, respectively. These results confirmed that it was more difficult for plants to grow in the hydroponic system than in the substrate-based system. A study conducted by Sorace et al. (2008) assessed the development of Cattleya skinneri on the substrate alone (no hydroponic cultivation) confirmed the advantages of the mixture used in the present study over other substrate formulations.

Table 2. Shoot and root dry masses of Oncidium baueri grown on substrates and hydroponically after 11 months of cultivation). Pelotas, UFPel, 2013/14.

\begin{tabular}{cccc}
\hline Dry mass & \multicolumn{2}{c}{ Cultivation system } & CV (\%) \\
\hline Shoot $(\mathrm{g})$ & $100.67 \mathrm{a}$ & $33.76 \mathrm{~b}$ & 15.41 \\
\hline Roots $(\mathrm{g})$ & $35.95 \mathrm{a}$ & $15.21 \mathrm{~b}$ & 10.51 \\
\hline
\end{tabular}

*Means in the row followed by the same letter did not significantly differ according to Tukey's test at a 5\% significance level.

Only the pot-cultivation system promoted blossom development up to eleven months after transplantation. In the October 2014 assessment, six plants bloomed and produced a mean of 35 flowers per plant.

Several characteristics of the NFT system may account for the growth responses of Oncidium baueri raised in it. The system has low thermal inertia which makes the nutrient solution and root zone temperatures directly dependent on air temperature (BURRAGE, 1992; GÁLVEZ; PEIL, 2000). Nutrient solutions that are $<15^{\circ} \mathrm{C}$ or $>30^{\circ} \mathrm{C}$ limit root uptake by interfering with biochemical processes (GOTO et al., 2001).
In the summer, the root systems were exposed to temperatures exceeding $30^{\circ} \mathrm{C}$ (Figure 2) and approaching $40^{\circ} \mathrm{C}$ during some hours of the day. This condition may have hindered root mineral absorption and caused an oxygen deficit in the solution (GÁLVEZ; PEIL, 2000). It may have also delayed plant adaptation, that is, the initial development of plants immediately after the transplantations performed in spring and the hot summer. During the colder months between May and August (Figure 2), root zone temperatures were probably suboptimal for several hours during the day, sometimes falling below $10^{\circ} \mathrm{C}$. This condition results in decreased metabolism, root water- and mineral uptake, root respiration, and overall plant growth. 
Although root zone temperature varies with that of the ambient environment, thermal inertia is higher in substrate-based cultivation than in hydroponic systems. In addition, unlike substratebased cultivation, there are no intervals between irrigations and water reserves in the hydroponic cultivation or, by extension, the root zone (ANDRIOLO et al., 2002). These facts may have contributed to greater water stress in plants during the high-temperature months.

It must be emphasized that this study was an initial investigation to be used as a basis for more detailed studies on Oncidium cultivation in hydroponic systems. Before dismissing the future use of hydroponic technology on this plant, additional research should be conducted to test other versions of the system. Modifications could include changing the size of the cultivation channels, the nutrient solution supply volume and intervals, and the materials used to root the seedlings. The cultivation channels could be fixed, and other hydroponic systems altogether such as aeroponics could be tested. These alterations may improve the suitability of this cultivation method for this plant species.

Cultivation in pots with substrates (carbonized rice husk, pine bark, and coconut fiber, 1:1:1) promoted increased growth, vegetative development, and flowering in Oncidium baueri Lindl. than did NFT hydroponic cultivation. The differences between the systems in terms of plant height and number of sprouts were apparent in the fifth and eighth months of cultivation, respectively.

\section{Acknowledgements}

We thank CAPES, FAPERGS, and CNPq for their financial support, the State University of Londrina for supplying the seedlings, and the Federal University of Pelotas for permitting us to use their research facilities.

\section{References}

ALBUQUeRQUE NeTO, A.; PEIL, R. M. N. Produtividade biológica de genótipos de tomateiro em sistema hidropônico no outono/inverno. Horticultura Brasileira, Brasília, v. 30, n. 4, p. 613-619, 2012.

ANDRIOLO, J. L.; BONINI, J. V.; BOEMO, M. P. Acumulação de matéria seca e rendimento de frutas de morangueiro cultivado em substrato com diferentes soluções nutritivas. Horticultura Brasileira, Brasília, v. 20, n. 1, p. 24-27, 2002.

ASSIS, A. M.; COLOMBO, L. A.; FARIA, R. T.; FONSECA, I. C. B. Longevidade pós-colheita de pseudobulbos com flores de Dendrobium nobile (Orchidaceae). Revista Brasileira de Horticultura Ornamental, Campinas, v. 9, n. 1, p. 85-87, 2003.

BURRAGE, S. W. Nutrient film technique in protected cultivation. Acta Horticulturae, Cairo, n. 323, p. 23-38, 1992.

CARRASCO, G.; IZQUIERDO, J. A. A média empresa hidropônica: a técnica da solução nutritiva recirculante (NFT). Talca: Universidade de Talca/FAO, 1996. 91 p.

COLOMBO, L. A.; FARIA, R. T.; ASSIS, A. M. A.; FONSECA, I. C. B. Aclimatização de um híbrido de Cattleya em substratos de origem vegetal sob dois sistemas de irrigação. Acta Scientiarum Agronomy, Maringá, v. 27, n. 1, p. 145-150, 2005.

CORTÉS, E. M. Características del riego en cultivo sin suelo: exigências en aportación y manejo. Resultados experimentales en cultivo de pepino en perlita. In: MILAGROS, M. F.; GÓMEZ, I. M. C. (Ed.). Cultivos sin suelo II. 2. ed. Almería: DGIFA-FIAPA - Caja Rural de Almería, 1999. p. 287-305.

GÁLVEZ, J. P.; PEIL, R. M. N. La modernidad del sistema de producción hortícola en El sudeste spañol. Plasticultura, Madrid, v. 1, n. 119, p. 44-81, 2000.

GOTO, R.; GUIMARÃES, V. F.; ECHER, M. M. Aspectos fisiológicos e nutricionais no crescimento e desenvolvimento de plantas hortícolas. In: FOLEGATTI, M. V.; CASARINI, E.; BLANCO, F. F.; BRASIL, R. P. C. do; RESENDE, R. S. (Coord.). Fertirrigação: flores, frutas e hortaliças. Guaíba: Agropecuária, 2001. p. 241268.

FAQUIM, V.; FURLANI, P. R. Cultivo de hortaliças de folhas em hidroponia em ambiente protegido. Informe Agropecuário, Belo Horizonte, v. 20, n. 200-201, p. 99104, 1999.

FARIA, R. T.; DALIO, R. J. D.; UNEMOTO, L. K.; SILVA, G. L. Propagação in vitro de Oncidium baueri Lindl. (Orchidaceae) sem uso de ágar. Acta Scientiarum 
Agronomy, Maringá, v. 28, n. 1, p. 71-74, 2006.

LORENZI, H.; SOUZA, H. M. Plantas ornamentais no Brasil. 3. ed. Nova Odessa: Plantarum, 2001. 1088 p.

MARQUES, G. N.; PEIL, R. M. N.; LAGO, I.; FERREIRA, L. V.; PERÍN, L. Fenologia, consumo hídrico, rendimento e qualidade de minimelancia em hidroponia. Revista de la Facultad de Agronomía (La Plata), Buenos Aires, v. 113, n. 1, p. 57-65, 2014.

NEVES, M. B.; BUZETTI, S.; CASTILHO, R. M. M.; BOARO, S. F. Desenvolvimento de plantas de girassol ornamental (Helianthus annuus L.) em vasos, em dois substratos com solução nutritiva e em solo. Científica, Jaboticabal, v. 33, n. 2, p. 127-133, 2005.

SORACE, M.; FARIA, R. T.; DAMASCENO, C. V.; GOMES, G. P.; BARBOSA, C. M.; VIEIRA, F. G. N.; SILVA, G. L.; TAKAHASHI, L. S. A.; SCHNITZER, J. A. Crescimento in vitro de Oncidium baueri (Orchidaceae) em diferentes concentrações de macronutrientes e sacarose. Semina: Ciências Agrárias, Londrina, v. 29, n. 4, p. 775-782, 2008.

STRASSBURGER, A. S.; PEIL, R. M. N.; FONSECA, L. A.; AUMONDE, T. Z. Crescimento vegetativo da abobrinha italiana em função da demanda de drenos. Revista Cientifica Rural, Santa Maria, v. 13, n. 2, p. 99110, 2011.

YAMAKAMI, J. K.; FARIA, R. T.; ASSIS, A. M.; REGO-OLIVEIRA, L. V. Cultivo de Cattleya Lindley (Orchidaceae) em substratos alternativos ao xaxim. Acta Scientiarum Agronomy, Maringá, v. 28, n. 4, p. 523-526, 2006.

ZANDONÁ, A. P.; FARIA, R. T.; LONE, A. B.; HOSHINO, R. T. Substratos alternativos ao esfagno na aclimatização de plântulas de Arundina graminifolia alba (Orchidaceae). Revista Brasileira de Horticultura Ornamental, Campinas, v. 20, n. 1, p. 7-12, 2014. 